(c) Elsevier/INRA

\title{
Methods of manipulating the microbial metabolism in the rumen
}

\author{
JP Jouany \\ INRA, Centre de Recherches de Clermont-Ferrand/Theix, 63122 Saint-Genès-Champanelle, France
}

(Received 23 September 1992; accepted 14 April 1993)

\begin{abstract}
Summary - We now have the means to increase or decrease the importance of the role of the rumen in ruminant digestion. The aim of these manipulations is to provide the animal with end products of digestion that are the best suited to the type of production required. We describe here the main additives and methods used to modify the rumen microbial population or its hydrolytic and fermentative activities: ionophore antibiotics; methane inhibitors; inhibitors of proteolysis or deamination; elimination of protozoa or fungi from the rumen; and probiotics. Some seem to have a welldefined action (inhibitors of methanogenesis and deamination), whereas others act on several targets (ionophore antibiotics, defaunation). The results observed in animal production depend on factors such as diet, type of production and the animal considered. The rumen should be considered as a balanced integrated system in which it is difficult to change only one variable. For example, the increase in the NADH/NAD ratio is related to the decrease in methanogenesis in the rumen but has repercussions on other factors concerning digestion, leading to a decrease in cellulolysis, deamination of amino acids and an increase in propionate or butyrate at the expense of acetate. The mode of action of some additives is not yet fully understood and the efficacy of probiotics has sometimes been openly contested. Studies presently in progress should make it possible to classify the different compounds on the market according to their effectiveness and to establish the conditions under which they should be used. Once the mechanisms of action are elucidated, research into new products will be more closely targeted. Genetic manipulation is an interesting approach to the control of the metabolism of rumen microbes but has so far yielded no concrete results.
\end{abstract}

rumen / microbes / fermentation / manipulation / feed additives / protozoa / defaunation / probiotics

Résumé - Modifications de la population microbienne dans le rumen. II est désormais possible de moduler l'importance du rumen dans la digestion chez le ruminant. Les manipulations mises en jeu ont pour objectif de fournir au ruminant les nutriments les mieux adaptés aux besoins de l'animal. Nous présentons les principaux moyens utilisés pour modifier la population microbienne, ou son activité hydrolytique ou fermentaire : les antibiotiques ionophores, les inhibiteurs de méthane, les inhibiteurs de protéolyse ou de désamination, les matières grasses, les substances ayant un effet "tampon", l'élimination des protozoaires ou des champignons, les probiotiques. Certains ont une action bien spécifique, tandis que d'autres agissent à plusieurs niveaux. Les résultats sur la production animale dépendent de facteurs tels que la nature de la ration, le type de production et les animaux concernés. Le rumen doit être considéré comme un système intégré en équilibre dans lequel il est difficile de changer un seul paramètre. Par exemple, l'augmentation du rapport NADH/ $N A D$ consécutif à une baisse de la méthanogenèse, a des répercutions sur d'autres facteurs diges- 
tifs : baisse de la cellulolyse et de la désamination des acides aminés, augmentation du propionate aux dépens de l'acétate. Le mode d'action de certains additifs n'est pas totalement connu, et l'efficacité des probiotiques est contestée. Les études en cours doivent permettre de préciser l'intérêt des traitements et les conditions dans lesquelles ils doivent être utilisés. Lorsque les mécanismes d'action seront mieux connus, il sera plus facile de définir les voies de recherche à développer pour proposer les produits et les conditions d'utilisation les plus efficaces. Les manipulations génétiques constituent une voie d'approche intéressante pour contrôler le métabolisme microbien dans le rumen. Toutefois les travaux réalisés jusque là n'ont pas pu aboutir à des résultats concrets sur l'animal.

rumen / microbes / fermentation / manipulation / additifs alimentaires / protozoaires / défaunation / probiotiques

\section{INTRODUCTION}

The ruminant has a compartment placed at the very beginning of the digestive tract called the rumen, in which more than $60 \%$ of total digestion takes place. In some diets, straw for example, as much as $90 \%$ of total digestion occurs in the rumen. Feed that has been ingested by the animal is broken down by the enzymes produced by the dense and varied microbial populations which live in anaerobiosis in the rumen ( $10^{6}$ protozoa, $10^{10}$ bacteria and $10^{4}$ fungi per $\mathrm{ml}$ ). The rumen wall does not secrete enzymes. Thus, microbial digestion is all important, and endogenous enzymatic digestion only involves the molecules that cannot be broken down in the rumen, either because the substrates are not in contact with the enzymes long enough or because the enzyme required is not present.

The products formed differ in nature and quantity depending on where feed is digested. Three different situations, as defined in the following examples, can be distinguished.

The digestion of starch in the intestine gives glucose whereas it forms volatile fatty acids (VFA) when digested in the rumen. These 2 end products (glucose and VFA) are both used as energy sources by the animal but not to the same degree of effectiveness. Depending on the type of production considered (milk or meat), and the quality of the products (fats or proteins), digestion could be promoted in either site.

Dietary proteins are broken down in the rumen into $\mathrm{NH}_{3}$, which is then partly excreted in the urine in the form of urea, whereas the same proteins give amino acids when digested in the small intestine. There is therefore an advantage in limiting the degradation of proteins in the rumen if the $\mathrm{N}-\mathrm{NH}_{3}$ needs of the microbes are met elsewhere by urea supplementation in the diet.

Forages with high cell-wall carbohydrate contents (cellulose, hemicellulose, pectic substances) are not digested in the small intestine. It is imperative therefore to stimulate their microbial digestion in the rumen. Part of the energy from the fermentation pathways is dispersed in the form of gas and heat. The rest of the energy provided by fermentation is used by the microbes for maintenance and growth. The microbial proteins synthesized are then digested in the small intestine.

The rumen could be bypassed to give the digestive tract of the ruminant the same characteristics as those of monogastric animals. This would be of particular interest for feed rich in high quality proteins and starch, and could be achieved by technological treatment of feed (heat, formaldehyde treatment of proteins, for example). 
In contrast, in animals receiving diets rich in forages and non-protein nitrogen, the microbial metabolism of the rumen may be enhanced. In this case the amino acids will be mainly supplied by the microbial proteins which leave the rumen with the digesta.

Only feed additives or modifications to the rumen microbial ecosystem will be dealt with here. Treatments made by the feed industry will not be considered.

\section{MANIPULATION OF THE RUMEN WITH CHEMICAL ADDITIVES}

Large numbers of molecules are currently being tested as feed additives in the ruminant (for a review, see Van Nevel, 1991). Most are used to act upon a specific function, but in fact they intervene at various levels to produce an overall effect on the animal.

We outline below the most common molecules or treatments in current use and those that are likely to lead to practical applications in the near future.

\section{Antibiotics}

Most of the antibiotics used as growth promotors in the ruminant have ionophore properties. Avoparcin is a glycopeptide antibiotic whose properties as a growthpromotor are similar to those of jonophore antibiotics, although it does not act on cation transport. Its antibiotic activity consists of inhibiting the incorporation of $N$ acetylglucosamine into the peptidoglycans of the bacterial cell walls.

incorporated at a dose of 20-30 ppm into feed, monensin, the most widely used ionophore antibiotic, increases feed efficiency (growth/feed intake) (Raun et al, 1976). It can either increase weight without a change in feed intake (in diets rich in forage) or maintain a weight increase for a smaller amount ingested (in diets rich in concentrates) (table I). The same results have also been observed with lasalocid (Spears and Harvey, 1984).

The mode of action of these molecules is now almost fully understood. They modify the microbial balance in the rumen by decreasing the number of Gram-positive

Table I. Influence of monensin on growth, feed intake and feed efficiency in growing cattle.

\begin{tabular}{|c|c|c|c|c|c|c|}
\hline & \multicolumn{2}{|c|}{$\operatorname{Diet} 1^{\mathrm{a}}$} & \multicolumn{2}{|c|}{ Diet $2^{b}$} & \multicolumn{2}{|c|}{ Diet $3^{\mathrm{c}}$} \\
\hline & $O$ mon ${ }^{d}$ & + mone & 0 mond & $+m o n e$ & 0 mon $\mathrm{d}$ & $+\operatorname{mon}^{\mathrm{e}}$ \\
\hline Animal number & 12 & 11 & 15 & 15 & 10 & 10 \\
\hline Live-weight gain $\left(g d^{-1}\right)$ & 1235 & 1243 & $1366^{f}$ & $1609 \mathrm{~g}$ & 1806 & 1816 \\
\hline Trial length $(d)$ & 183 & 181 & 56 & 56 & 61 & 61 \\
\hline Dry matter intake $\left(\mathrm{kg} \mathrm{d}^{-1}\right)$ & $7.4^{f}$ & $6.9 \mathrm{~g}$ & 8.4 & 8.4 & 12.9 & 12.7 \\
\hline Dry matter intake $/ \mathrm{kg}$ live-weight gain & 6.0 & 5.6 & 6.2 & 5.2 & 7.1 & 7.0 \\
\hline
\end{tabular}

\footnotetext{
a Diet 1: $25 \%$ dehydrated lucerne $+50 \%$ dehydrated sugar-beet pulp $+25 \%$ concentrate; ${ }^{b}$ diet 2 : grass $+1 \mathrm{~kg}$ corn; ${ }^{c}$ diet 3: $70 \%$ corn $+30 \%$ dehydrated lucerne; d 0 mon: no added monensin; ${ }^{\text {e }}+$ mon: monensin added at $20-30 \mathrm{ppm}$ in feed. Means with different superscript letters on a line were significantly difterent $(P<0.05)$. Data reproduced from Geay et al (1977).
} 
bacteria and fungi, and sometimes protozoa, to the benefit of other components of the microbial ecosystem. Their antibiotic action is due to a decrease in the proton gradient between the inside and outside of the cells, resulting in a decrease in protonmotive force (chemical gradient and cellwall potential), which is one of the sources of ATP formed in the bacteria (Bergen and Bates, 1984). In addition, the bacteria consume ATP by reversing the functioning of their ATP-ATPase system so as to expel the excess intracellular protons in the presence of ionophores (Bergen and Bates, 1984).

Ionophore antibiotics significantly increase the production of propionate $(+25 \%$ of the propionate molar proportion) at the expense of acetate and butyrate production (table II). In correlation, methane production is decreased as is the degradation of amino acids from the hydrolysis of nutritional and microbial proteins. Lactate production is also greatly reduced, which limits the risks of acidosis with diets rich in easily fermentable carbohydrates (Nagaraja et al, 1985).

It seems therefore that ionophore antibiotics used as feed additives in ruminants act on both the energy and nitrogen metabolism of animals. It is estimated that the increase in propionate in the VFA mixture leads to an improvement of about $5 \%$ in energy retained as VFA. But this only explains part of the improvement in animal performance observed (Raun et al, 1976). Experiments made with fistulated animals showed that while the supply of duodenal amino acids from feed increased after treatment with ionophore antibiotics, there were fewer microbial proteins produced (Gomez et al, 1991). The nature of the amino acids changed, but overall their daily flow was not altered (table III). Mac Gregor and Armstrong (1984) showed that avoparcin improved the absorption of amino acids in the small intestine of sheep by increasing the activity of dipeptidases produced in the intestinal mucosa.

Table II. In vivo effect of ionophore antibiotics on the end products of rumen fermentation.

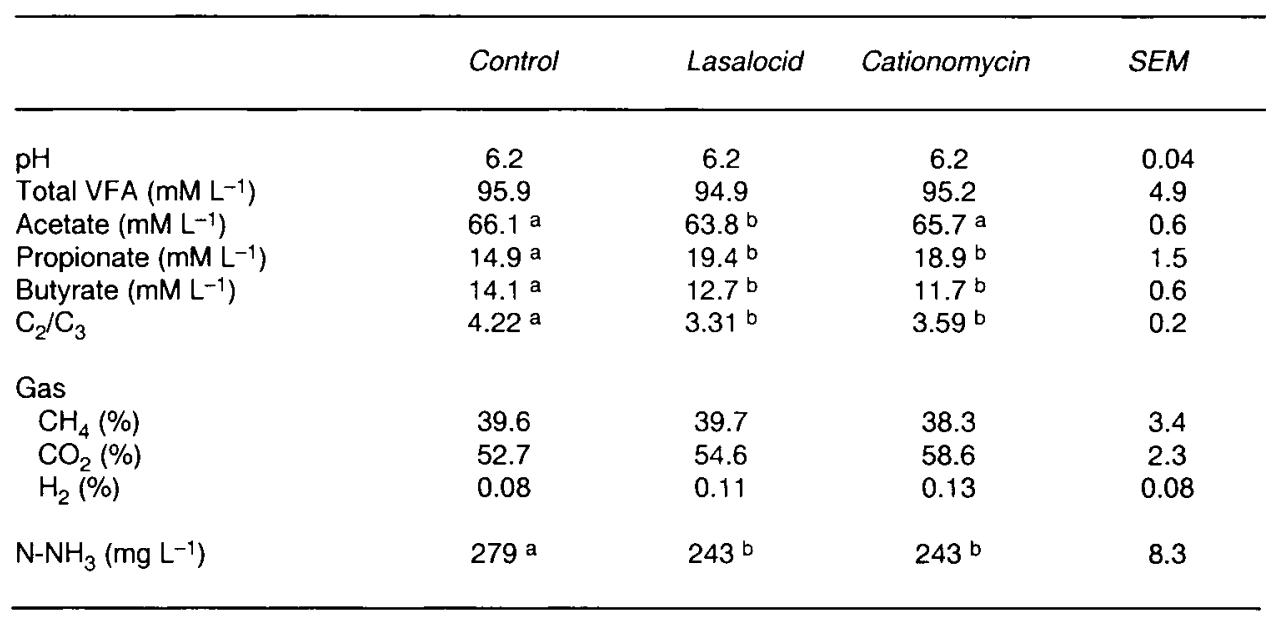

Means with different superscript letters on a line were significantly different $(P<0.05)$. Data reproduced from Bogaert et al (1991). 
Table III. Effect of lasalocid and cationomycin on the duodenal flow of nitrogen.

\begin{tabular}{lcccc}
\hline & Control & Lasalocid & Cationomycin & SEM \\
\hline $\mathrm{N}^{*}$ intake $\left(\mathrm{g} \mathrm{d}^{-1}\right)$ & 26.5 & 26.5 & 26.9 & 1.7 \\
& & & & \\
Duodenal flows $\left(\mathrm{g} \mathrm{d}^{-1}\right)$ & 20.3 & 19.7 & 19.2 & 3.3 \\
$\quad$ Total $\mathrm{N}$ & 1.3 & 1.1 & 1.0 & 0.1 \\
$\mathrm{NH}_{3}-\mathrm{N}$ & 19.0 & 18.5 & 18.2 & 1.7 \\
Total non- $\mathrm{NH}_{3}-\mathrm{N}$ & $15.3^{\mathrm{a}}$ & $12.5^{\mathrm{b}}$ & $10.7^{\mathrm{b}}$ & 1.2 \\
Microbial N & $3.6^{\mathrm{a}}$ & $6.0^{\mathrm{b}}$ & $7.3^{\mathrm{b}}$ & 1.1 \\
Dietary N * & & & & \\
\hline
\end{tabular}

$\mathrm{N}=$ nitrogen; $\mathrm{NH}_{3}-\mathrm{N}=$ ammonia nitrogen; * residual $\mathrm{N}=$ (total non- $\left.\mathrm{NH}_{3}-\mathrm{N}\right)-($ microbial $\mathrm{N})$; residual $\mathrm{N}$ is considered as dietary $\mathrm{N}$. Means with different superscript letters on the same line were different $(P \geq 0.05)$. Data reproduced from Gomez et al (1991).

As propionate and some amino acids are used for gluconeogenesis, an increase in the former can reduce the proportion of the latter. In this way, amino acids are spared. Monensin, considered as a model molecule in this group of compounds, has no effect on post-ruminal digestion (Rogers et al, 1991). However, it can modify the hormonal state of animals (Villareal Arredondo, 1988), and it was shown that the age of puberty could be brought forward in female animals that have been treated. It is likely that these changes have repercussions of the animal's metabolism and on tissue metabolism.

The use of these compounds has to be controlled because they are highly active and it is difficult to be certain that there will be no toxic residues or metabolites in the milk or meat bought by consumers. These products are widely used in poultry against coccidosis. The aim of research is to find products that are effective at very low doses (such as tetronasin, $6 \mathrm{ppm}$ ) and whose toxicity is lower (cationomycin, abierixin) than that of the molecules currently in use.

\section{Methane inhibitors}

Up to $10 \%$ of the gross energy of animal feed is lost in the form of methane. The production of $\mathrm{CH}_{4}$ by rumen microbes and that of $\mathrm{CO}_{2}$, estimated at 400 and $600 \mathrm{~L} \mathrm{~d}^{-1}$ respectively in adult cattle, contribute to the greenhouse effect which is now threatening our planet. Ruminants are responsible for $27 \%$ of total methane production, and methane is one of the most potent greenhouse gases, being responsible for $18 \%$ of the total phenomenon (Johnson et al, 1991). Recent research into ways of diminishing $\mathrm{CH}_{4}$ production has shown that a large number of molecules, in particular long-chain fatty acids and the halogen homologues of $\mathrm{CH}_{4}$, are active (Van Nevel and Demeyer, 1988). When methanogenesis is inhibited there is a decrease in the $\mathrm{NAD/NADH}$ ratio, which is unfavourable to fermentative processes in an anaerobic environment. This explains the lower deamination of amino acids, in particular of branched-chain amino acids, which is observed when $\mathrm{CH}_{4}$ production is inhibited (Hino and Russell, 1985). The increase in 
propionate or butyrate production that usually occurs when methanogenesis is reduced uses the excess hydrogen formed and re-establishes a normal NAD/NADH ratio (Russell and Martin, 1984). Halogen compounds (bromide or chloride) have a direct toxic effect on methanogenic bacteria (Prins et al, 1972; Sparling and Daniels, 1987).

Some of these products have been tested on animals in production. Beneficial effects were observed in diets rich in forages, which favour the production of methane (Davies et al, 1982). Partial adaptation of methanogenic bacteria to these additives has been found. Rumen microbes succeed in degrading them after about 1 month of treatment (Chalupa, 1980). Chloroform alone is able to resist, but because of its volatility it is difficult to use.

A precise assessment of the interest of decreasing methane production should include the energy metabolism of rumen microbes engendered during the fermentative processes under anaerobiosis. Furthermore, the gain in ATP achieved during the formation of methane has repercussions on how effectively microbial proteins are synthesized, with the risk of their levels being lowered if methanogenesis is inhibited.

\section{Inhibitors of proteolysis or deamination}

One of the main aims in improving nitrogen use by the ruminant is to inhibit the degradation of amino acids in the rumen up to the ammonia stage. Several types of product have been tested to this end.

\section{Compounds belonging to the diaryliodonium family}

These compounds limit the degradation of amino acids by inhibiting their transport through the cell wall of bacteria (Chalupa et al, 1983). They have been clearly shown to have a negative effect on Bacteroides ruminicola, which plays an essential role in the degradation of amino acids in the rumen. Consequently, they improve nitrogen retention in the animals.

These compounds also cause a decrease in methanogenesis during protein fermentation without changing propionate proportions. With starch as substrate, methane is also diminished, but propionate increases considerably (Van Nevel and Demeyer, 1990). The concentration of free hydrogen is not changed (Chalupa et al, 1983). This means that they act on methane precursors rather than on methanogenic bacteria.

\section{Hydrazin-type compounds $\left(\mathrm{NH}_{2}-\mathrm{NH}_{2}\right)$}

These products have a clear inhibitory effect on the degradation of rumen amino acids. However, their high toxicity excludes their use in animal feed (Broderick and Balthrop, 1979).

\section{MODIFICATIONS CAUSED BY SUPPLIES OF CERTAIN FOOD CONSTITUENTS}

\section{Addition of large amounts of lipids to the diet}

The addition of large amounts (up to $10 \%$ ) of lipids to the diet of dairy cows with a high production potential satisfies the animals' considerable energy requirements. The changes observed in the rumen metabolism are sufficiently large for these compounds to be considered as additives.

They bring about a decrease in methane production associated with a drop in the molar percentage of acetic and butyric 
acid. In contrast, the proportion of propionic acid is increased. The flow of microbial proteins in the duodenum is frequently larger whereas the amount of fermented organic matter (FOM) in the rumen diminishes, which tends to improve the yield of microbial synthesis (microbial $\mathrm{N} / \mathrm{mol}$ ATP or $\mathrm{kg}$ FOM). The digestion of the cell-wall fraction of feed is most affected by the addition of lipids.

For a long time it was thought that lipids coated feed particles, preventing cellulolytic bacteria from adhering to them. It is now known that fatty acids have a direct toxic effect on the rumen microbial population (Broudiscou et al, 1990). Unsaturated, and in particular polyunsaturated longchain fatty acids seem to be more active than saturated ones. They are particularly active against protozoa and, if present in large quantities, may even defaunate the rumen. This may explain the positive effect of lipids on microbial protein synthesis. Studies made on pure bacteria cultures have shown that methanogenic bacteria are very sensitive to these fatty acids. Gram-negative bacteria, which have an important role in the formation of propionate, are much less sensitive than Grampositive bacteria (Henderson, 1973).

Most of the negative effects of the fatty acids disappear, or are at least greatly diminished, when the lipids are present in the form of insoluble calcium soaps or as protected lipids.

\section{Addition of buffer substances}

These compounds are used to regulate the $\mathrm{pH}$ and to maintain it at levels at which the cellulolytic microorganisms can be of maximum effectiveness ( $\mathrm{pH}=6-7)$. They are particularly recommended in animals receiving diets rich in energy concentrates, which induce active fermentation and cause an excess production of acids after feed intake. The buffer substances used are $\mathrm{NaHCO}_{3}, \mathrm{Na}_{2} \mathrm{CO}_{3}, \mathrm{CaCO}_{3}$ and $\mathrm{MgO}$. The addition of these compounds generally results in an increase in the turnover rate in the liquid phase of the rumen contents, which offsets the risks of an increase in the osmotic pressure of the medium. The greater efficiency of microbial synthesis and the increase in the proportion of acetate in the mixture of VFAs formed can be directly linked to the faster turnover rate of rumen fluid (Harrison et al, 1975). The digestion of starch and proteins is generally decreased when feed is observed to have a shorter retention time in the rumen. The lack of effect on cell-wall carbohydrate digestion with the addition of these buffers or the improvement sometimes reported are both due to the higher activity of the cellulolytic bacteria, which benefit from better conditions in the medium $(\mathrm{pH})$.

The $\mathrm{pH}$ can also be controlled and the turnover rate of the rumen liquid phase increased by the use of pharmaceutical products (slafranin, carbachol, pilocarbine) that stimulate the animal's saliva production (Froetschel et al, 1989; Wiedmeier et al, 1987). These products can only be used for experimental purposes.

\section{DIRECT MODIFICATIONS OF THE MICROBIAL ECOSYSTEM}

\section{The elimination of rumen protozoa (defaunation)}

Although protozoa play an important role in rumen digestion, the ruminant does not need them to live. Protozoa can be completely eliminated from the rumen to study their real effect on digestion indirectly (Jouany et al, 1988). 


\section{The effect of defaunation on nitrogen digestion in the rumen}

By comparing the ability of microbial inocula from the rumen of defaunated and faunated animals to degrade different proteins, Ushida and Jouany (1985) showed that the elimination of the protozoa reduced the proportion of nitrogen fermented to the $\mathrm{NH}_{3}$ stage by about $10 \%$. The maximum value of the degradation of soyabean proteins measured in situ was also decreased by about $6 \%$ by defaunation (table IV). Ushida et al (1989) showed that in

Table IV. Effect of protozoa on degradability of soyabean cake measured in sacco $^{\text {a }}$.

\begin{tabular}{lccc} 
Parameters $^{\mathrm{a}}$ & $\begin{array}{l}\text { Faunated } \\
\text { animals }\end{array}$ & $\begin{array}{c}\text { Defaunated } \\
\text { animals }\end{array}$ & SEM $^{\mathrm{b}}$ \\
\hline $\mathrm{a}(\%)$ & 15.1 & 15.1 & 0.8 \\
$\mathrm{a}+\mathrm{b}(\%)$ & 84.9 & $79.8^{* *}$ & 1.7 \\
$\mathrm{c}\left(\mathrm{h}^{-1}\right)$ & 10.4 & $9.1^{*}$ & 0.2
\end{tabular}

a According to Ørskov and McDonald (1979). Means on a same line are significantly different: * $p<0.05$; "* $p<$ 0.01 . Data reproduced from Ushida and Jouany (1985). vivo protein degradation is also lowered after defaunation.

The absence of protozoa enhances the synthesis of rumen microbial proteins (table V). This is because the bacteria make up the main source of protein for the protozoa and because a large part of the protozoa biomass $(60-80 \%)$ is entrapped in the rumen where it dies without being used by the animal (Harrison and McAllan, 1990).

The 2 sources of amino acids supplied in the duodenum, undegraded dietary proteins and microbial proteins, are therefore greatly increased (by about $50 \%$ ) by defaunation (Jouany, 1991) whatever the type of animal or feeding regime. Of course, this effect of defaunation is enhanced in diets poor in protein (Demeyer et al, 1982).

\section{The influence of protozoa on the digestion of plant cell walls}

Most in vivo experiments show that the elimination of protozoa decreases plant cell-wall digestion in the rumen by about $30 \%$, a decrease that is partly compensated for in the large intestine. This shift in digestion increases nitrogen and energy

Table V. Effect of defaunation on duodenal nitrogen flow $\left(\mathrm{g} \mathrm{d}^{-1}\right)$.

\begin{tabular}{|c|c|c|c|c|c|c|c|}
\hline & \multicolumn{2}{|c|}{$N A N^{a}$} & \multicolumn{2}{|c|}{ Feed N } & \multicolumn{2}{|c|}{ Microbial N } & \multirow{2}{*}{$\begin{array}{r}\text { Protozoa N } \\
\text { in duodenum } \\
(\% \text { microbial N) }\end{array}$} \\
\hline & $F^{b}$ & $D^{\mathrm{c}}$ & $F$ & $D$ & $F$ & $D$ & \\
\hline \multirow[t]{2}{*}{ Meyer et al, 1986} & 19 & 22 & 7 & 5 & 8 & $16^{*}$ & 36 \\
\hline & - & - & - & - & 12 & $17^{*}$ & - \\
\hline \multirow[t]{2}{*}{ Ushida et al, 1986} & 24 & 30 & 9 & 11 & 15 & 19 & 7 \\
\hline & - & - & 8 & 12 & 16 & 18 & - \\
\hline \multirow[t]{2}{*}{ Ushida et al, 1990} & 13 & $16^{*}$ & 8 & 8 & 6 & $8^{*}$ & 22 \\
\hline & 13 & $19^{*}$ & 7 & 9 & 7 & $9^{*}$ & 32 \\
\hline
\end{tabular}

\footnotetext{
${ }^{a}$ Nan: non-ammonia nitrogen; ${ }^{\mathrm{b}} \mathrm{F}$ : animals; ${ }^{\mathrm{c}} \mathrm{D}$ : defaunated animals. "Effect of defaunation is significant $(P<0.05)$.
} 
excretion in the faeces and should therefore be taken into account when the effects of defaunation are assessed. However, an Australian team has, on several occasions, observed a positive effect of defaunation on plant cell-wall digestion, which has yet to be fully explained. Work is in progress in our laboratory to elucidate this discrepancy.

According to Ushida et al (1990, 1991), the positive effects of protozoa on cell-wall digestion is particularly marked in diets supplemented with starch, which decreases the digestion of cell-wall carbohydrates. Protozoa have greatest effect on the digestion of hemicellulose $(+53$ for hemicellulose versus $+23 \%$ for cellulose).

Protozoa are known to have a negative effect on the population of rumen amylolytic bacteria (Kurihara et al, 1978). This is a result of the competition between microorganisms for the use of this substrate and the particular ability of the protozoa to ingest starch grains and the bacteria attached to them. Hence, the rumen medium is more buffered (less wide variations in $\mathrm{pH}$; more regular production of volatile fatty acids during the day). These conditions are favourable to the development of cellulolytic bacteria, which act in conjunction with the protozoa (large Ophryoscolecidae) against plant cell walls. The effects of protozoa on the rumen fungal population are not known. Recent data (Jouany, 1991) show that their numbers are higher or remain stable after defaunation of the rumen.

It is difficult to integrate physiological variables (such as the retention time of feed in the rumen and the volume of rumen digesta) into the assessment of the overall effect of the protozoa on digestion, even though it is acknowledged that their influence may be considerable. However, the evolution of physiological parameters according to the rumen fauna can vary greatly between animals (Jouany et al, 1988).

\section{The influence of protozoa on the end products of digestion in the rumen}

Defaunation often results in a decrease in the production of VFA (table VI); at best, it has no effect. This is in agreement with results obtained on the digestion of organic matter in the rumen. The disappearance of protozoa is generally associated with a decrease in the proportion of butyrate to the advantage of propionate or acetate in the mixture of VFA.

Contrary to holotrich ciliates, entodiniomorph ciliates metabolise lactic acid and limit the risks of acidosis caused by the excessive intake of fermentable carbohydrates (starch and sugar). This is a further example of the buffering effect of the protozoa described above.

Defaunation always decreases the concentration of $\mathrm{N}^{-\mathrm{NH}_{3}}$ in the rumen. This could be a direct result of the reduced degradation of the dietary and microbial proteins since $\mathrm{NH}_{3}$ uptake by bacteria is not altered (Itabashi and Kandatsu, 1975). This systematic decrease in $\mathrm{N}-\mathrm{NH}_{3}$ concentration cannot be explained by any change in $\mathrm{N}$ recycling or $\mathrm{N}$ absorption through the rumen wall or by any change in rumen volume.

The lower methanogenic activity observed after defaunation of the rumen $(-30$ to $-45 \%$ ) by decreasing energy losses, can be of considerable benefit to animals with a high production potential (Whitelaw et al, 1984).

\section{The influence of protozoa on dietary toxins}

Protozoa can transform the toxins that are present in feed or in the yeasts that develop on feed (Kiessling et al, 1984). Defaunated animals are also more sensitive to copper toxicity (Ivan et al, 1986). Protozoa enhance the formation of copper sulphide 
Table VI. Effect of defaunation on VFA and ammonia nitrogen concentration in the rumen.

\begin{tabular}{|c|c|c|c|c|c|c|c|c|c|c|c|}
\hline \multirow[t]{3}{*}{ Authors } & \multirow{3}{*}{$\begin{array}{l}\text { Proportion of } \\
\text { concentrate } \\
\text { in diet }\end{array}$} & \multirow{2}{*}{\multicolumn{2}{|c|}{$\begin{array}{c}V F A \\
\left(m M L^{-1}\right)\end{array}$}} & \multicolumn{6}{|c|}{ Molar (\%) } & \multirow{2}{*}{\multicolumn{2}{|c|}{$\begin{array}{l}\mathrm{NH}_{3}-\mathrm{N} \\
\left(m g L^{-1}\right)\end{array}$}} \\
\hline & & & & \multicolumn{2}{|c|}{$C_{2}$} & \multicolumn{2}{|c|}{$c_{3}$} & \multicolumn{2}{|c|}{$C_{4}$} & & \\
\hline & & $F^{a}$ & $D^{\mathrm{b}}$ & $F$ & $D$ & $F$ & $D$ & $F$ & $D$ & $F$ & $D$ \\
\hline Jouany et al, 1981 & 49 & 91 & $83^{*}$ & 66 & 66 & 15 & $22^{*}$ & 16 & $9^{*}$ & 260 & $140^{*}$ \\
\hline Itabashi et al, 1982 & 50 & 112 & 113 & 71 & 71 & 16 & $21^{*}$ & 11 & $6^{*}$ & 132 & $55^{\star}$ \\
\hline Jouany and Sénaud, 1982 & 0 & 90 & $78^{*}$ & 72 & 73 & 17 & 19 & 7 & $5^{*}$ & 178 & $137^{\star}$ \\
\hline Jouany and Sénaud, 1982 & 59 & 116 & $103^{*}$ & 61 & 59 & 30 & $35^{*}$ & 8 & $4^{\star}$ & 242 & $164^{*}$ \\
\hline Jouany, 1978 & 71 & 111 & $75^{*}$ & 53 & $57^{\star}$ & 27 & $21^{*}$ & 19 & $16^{*}$ & 262 & $150^{*}$ \\
\hline Itabashi et al, 1984 & 0 & - & - & 64 & 64 & 20 & 23 & 12 & 17 & 51 & $25^{\star}$ \\
\hline Rowe et al, 1985 & 50 & 77 & 89 & 61 & 57 & 25 & 23 & 12 & 17 & 104 & 104 \\
\hline Ushida et al, 1986 & 0 & 66 & 58 & 71 & 72 & 17 & $20^{*}$ & 9 & $6^{*}$ & 191 & $98^{*}$ \\
\hline Ushida et al, 1986 & 30 & 82 & 74 & 66 & 65 & 17 & $22^{*}$ & 13 & $10^{*}$ & 140 & $54^{*}$ \\
\hline Ushida et al, 1990 & 0 & 72 & 70 & 71 & $74^{*}$ & 20 & 20 & 7 & $5^{\star}$ & 167 & $68^{*}$ \\
\hline Ushida et al, 1990 & 20 & 66 & 58 & 69 & $72^{*}$ & 19 & 19 & 9 & $7^{\star}$ & 134 & $59^{\star}$ \\
\hline
\end{tabular}

a Faunated animals; b defaunated animals. " Effect of defaunation was significant $(P<0.05)$.

which cannot be absorbed in the digestive tract and, therefore, metabolised by the animal.

\section{The overall effect of protozoa on animal performance}

Published reports on this topic give conflicting results (Jouany, 1991). It is clear that the elimination of protozoa results in a greater supply of amino acids to the duodenum (table V), which also explains why young defaunated animals receiving low protein diets and whose nitrogen needs are high have greater liveweight gain after defaunation. However, in diets rich in roughage supplemented with native starch, the presence of protozoa may be beneficial.

While no definite conclusions can be drawn, it seems that defaunation has a positive effect on animal performance when diets supplemented with sugar (mo- lasses) are given (Bird and Leng, 1978; Bird et al, 1979).

\section{THE ELIMINATION OF ANAEROBIC FUNGI FROM THE RUMEN}

Most attempts to eliminate anaerobic fungi from the rumen in vivo experiments have failed. This aim was achieved only in one experiment by feeding animals with sodium chlorite-treated straw (Ford et al, 1987). The addition of ionophore antibiotics to eliminate the fungi (Elliott et al, 1987) was unsuccessful in our institute (Grenet et al, 1989). The lowering of the $\mathrm{pH}$ of the rumen fluid to 5.5 by the addition of large amounts of soluble sugar eliminated the fungi for a few hours only and, furthermore, had negative effects on the other components of the microbial ecosystem (Grenet et al, 1989). When rumen fluid was treated in vitro with cycloheximide 
(50 mg L-1), the fungi were permanently eliminated (Hillaire et al, 1990), and further experiments were made to determine their role in digestion.

Fungi greatly improved the digestion of wheat straw $(+28 \%)$ with particularly marked effects on cellulose $(+50 \%)$ and hemicellulose (+33\%) (Hillaire et al, 1990). In the same experiment, it was shown that fungi had no effect on the digestion of pectic substances. When fungi were present, the production of VFA and of gas increased by 48 and $66 \%$, respectively, indicating that the microorganisms play an important role in the fermentative processes of the rumen by inducing a greater production of acetate during fermentation to the detriment of propionate. At the same time, the $\mathrm{CO}_{2} / \mathrm{CH}_{4}$ ratio decreased in the gas mixture.

\section{Probiotics}

Certain yeasts and living fungi (Saccharomyces, Aspergillus) are now used as probiotics in ruminants. Distributed at a rate of $10 \mathrm{~g} \mathrm{~d}^{-1}$ (concentration $10^{5} \mathrm{CFU} \mathrm{g}^{-1}$ rumen content) to adult cows, mixed in with their culture medium, these probiotics have, in certain cases, considerably increased milk production (by $1.2 \mathrm{~L} \mathrm{~d}^{-1}$ ) without altering the composition of the milk (Williams and Newbold, 1990). Improvements were also noted in the performance of growing animals. Their effects are strain-dependant.

Probiotics have a clearcut effect when used in forage-based diets supplemented with at least $30 \%$ cereals (Williams and Newbold, 1990) and in those supplemented with sucrose. They improved the digestion of the cell-wall constituents of forages (Wohlt et al, 1991) and increased the flow of microbial proteins in the duodenum of the animals treated (Erasmus et al, 1992).
Their precise mode of action is not fully understood. They have been observed to regulate fermentation by limiting the drop in $\mathrm{pH}$ after the meal and to decrease the production of lactate in the rumen, both of which are conditions particularly favourable to the development of cellulolytic bacteria. Although they actively use soluble substrates, they are mainly found in the solid phase of digesta (Jouany et al, 1991). It is possible that they rapidly metabolise the carbohydrates solubilized from starch and cellulose by amylolytic and cellulolytic bacteria, or present in the form of sugars in the diet, to form products that can be metabolised by the microbial ecosystem without the formation of $\mathrm{H}^{+}$ions. The effects of probiotics in ruminants is probably not restricted to the rumen since they reach the intestine where it is likely that they have an action similar to that observed in monogastrics (Vanbelle et al, 1990).

After a long period in which little attention was given to the subject, workers are now developing research on the use of probiotics in the ruminant. Studies in progress should enable scientists to understand their mode of action and select the most efficient strains.

\section{Genetic manipulation of rumen microbes}

There are several teams in the world currently working in this field. Recombinant DNA and molecular biology techniques have been developed to improve the digestion of cell-wall carbohydrate in herbivores, to limit the degradation of proteins in the rumen or produce more microbial amino acids, to inhibit the growth or metabolic activity of undesirable organisms, and to produce substances that are of benefit to the microbes or the host animal (Forano, 1991). 
Most of the work so far has consisted of cloning genes of rumen cellulolytic bacteria in the well-known genetic system of Escherichia coli. The cleaved DNA fragments are inserted into a vector plasmid that will replicate in $E$ coli. The recombinant plasmids are introduced into the cell by transformation or by conjugation. A genomic library can then be established.

There have been at least 50 scientific reports on the cloning of gene coding for fibre-degrading enzymes. Most experiments were carried out on $F$ succinogenes, $R$ albus, $R$ Flaveciens, $B$ fibrisolvens and $B$ ruminicola.

Trials have been carried out to implant the replicate bacterium in the rumen but, to our knowledge, without success. The genetically engineered bacteria were swiftly eliminated from the rumen. There could be a greater chance of success if native rumen bacteria were used as hosts. To be efficient, the genetically engineered microorganisms must inhabit an important ecological niche in the rumen and the newly acquired genes must be maintained.

These are only the most striking aspects of genetic manipulation in which reside the future hopes of research workers since, in theory, molecular biology offers enormous scope for development. However, this manipulation is also disturbing, since it modifies an equilibrium that is the result of millions of years of natural selection.

\section{REFERENCES}

Bergen WG, Bates DB (1984) Ionophores: their effect on production efficiency and mode of action. J Anim Sci 58, 1465-1483

Bird S, Leng RA (1978) The effects of defaunation of the rumen on the growth of cattle on low-protein, high-energy diets. Br J Nutr 40 , 163-167

Bird S, Hill MK, Leng RA (1979) The effects of defaunation on the growth of lambs on low- quality, high-energy diets. $B r J$ Nutr 42,81 87

Bogaert C, Gomez L, Jouany JP (1991) Effects of lasalocid and cationomycin on the digestion of plant cell walls in sheep. Can J Anim Sci $71,379-388$

Broderick GA, Balthrop JE (1979) Chemical inhibition of amino-acid deamination by ruminal microbes in vitro. $J$ Anim Sci 49, 11011111

Broudiscou L, Van Nevel CJ, Demeyer DI (1990) Effect of soja oil hydrolysate on rumen digestion in defaunated and refaunated sheep. Anim Feed Sci Technol 30, 51-67

Chalupa W (1980) Chemical control of rumen microbal metabolism. In: Digestive Physiology and Metabolism in Ruminants ( $Y$ Ruckebusch, $P$ Thivend, eds) MTP Press Ltd, Lancaster, UK, 325-347

Chalupa W, Patterson JA, Parish RC, Chow AW (1983) Effects of diaryliodonium chemicals on rumen fermentation in vitro and in vivo. J Anim Sci 57, 186-194

Davies A, Nwaonu HN, Stanier G, Boyle FF (1982) Properties of a novel series of inhibitors of rumen methanogenesis: in vitro and in vivo experiments including growth trials on 2,4-bis-(trichloromethyl)-benzo-1,3-dioxin-6carboxylic acid. Br J Nutr 47, 565-576

Demeyer DI, Van Nevel CJ, Van de Voorde G (1982) The effect of defaunation on the growth of lambs fed three urea-containing diets. Arch Tierernähr 32, 595-604

Elliott R, Ash AJ, Calderon-Cordes F, Norton BW, Bauchop T (1987) The influence of anaerobic fungi on rumen volatile fatty acid concentrations in vivo. J Agric Sci 109, 13-17

Erasmus LJ, Botha PM, Kistmer A (1992) Effect of yeast culture supplement on production, rumen fermentation, and duodenal flow in dairy cows. J Dairy Sci 75, 3056-3065

Forano $E$ (1991) Recent progress in genetic manipulation of rumen microbes. In: Rumen Microbial Metabolism and Ruminant Digestion (JP Jouany, ed) INRA Editions, Versailles, France, 89-103

Ford CW, Elliott R, Maynard PJ (1987) The effect of chlorite delignification on digestibility of some grass forage and on intake and rumen microbial activity in sheep fed barley straw. J Agric Sci, Camb 108, 129-136

Froetschel MA, Amos HE, Evans JJ, Croom WJ Jr, Hagler WM Jr (1989) Effects of a salivary 
stimulant, slaframine, on ruminal fermentation, bacterial protein synthesis and digestion in frequently fed steers. J Anim Sci 67, 827-834

Geay $Y$, Jouany JP, Beranger C (1977) Utilisation du rumensin pour l'engraissement des bovins. Bull Techn CRVZ Theix 30, 73-78

Gomez L, Bogaert C, Jouany JP, Lassalas B (1991) The influence of lasalocid and cationomycin on nitrogen digestion in sheep; comparison of methods for estimating microbial nitrogen. Can J Anim Sci 71, 389-399

Grenet E, Fonty G, Jamot J, Bonnemoy F (1989) Influence of diet and monensin on development of anaerobic fungi in the rumen, duodenum, cecum, and feces of cows. Appl Environ Microbiol 55, 2360-2364

Harrison DG, McAllan AB (1990) Factors affecting microbial growth yields in the reticulorumen. In: Digestive Physiology and Metabolism in Ruminants ( $\mathrm{Y}$ Ruckebush, $\mathrm{P}$ Thivend, eds) MTP Press, Ltd, Lancaster, UK, 205-226

Harrison DG, Beever DE, Thomson DJ, Osbourn DF (1975) Manipulation of rumen fermentation in sheep by increasing the rate of flow of water from the rumen. J Agric Sci 85, 93-101

Henderson C (1973) The effect of fatty acids on pure culture of rumen bacteria. $J$ Agric Sci 81, 107-112

Hillaire MC, Jouany JP, Fonty G (1990) Wheat straw degradation in Rusitec, in the presence or absence of rumen anaerobic fungi. Proc Nutr Soc 49, 127A

Hino T, Russell JB (1985) Effect of reducing equivalent disposal and NADH/NAD on deamination of amino acids by intact rumen microorganisms and their cell extracts. Appl Environ Microbiol 50, 1368-1374

Itabashi H, Kandatsu M (1975) Influence of rumen ciliate protozoa on the concentration of ammonia and volatile fatty acids in connection with the utilization of ammonia in the rumen. Jpn J Zootech Sci 46, 409-416

Itabashi $\mathrm{H}$, Kobayashi T, Matsumoto M (1984) The effects of rumen ciliate protozoa on energy metabolism and some constituents in rumen fluid and blood plasma of goats. Jpn J Zootech Sci 55, 248-255

Itabashi $H$, Kobayashi $T$, Morii $R$, Okamoto $S$ (1982) Effects of ciliate protozoa on the concentration of ruminal and duodenal volatile fatty acids and plasma glucose and insulin after feeding. Bull Natl Inst Anim Ind 39, 21-32
Ivan M, Veira DM, Kellecher CA (1986) The allievation of chronic copper toxicity in sheep by ciliate protozoa. Br J Nutr 55, 361-367

Johnson DE, Branine M, Ward GM, Carmean B, Lodman D (1991) The potential contribution of beef cattle methane to global warming: background information and perspectives. In: Beef Program Report, Anim Sci Dept CSU, USA, 1-8

Jouany JP (1978) Contribution à l'étude des protozoaires ciliés du rumen : leur dynamique, leur rôle dans la digestion et leur intérêt pour le ruminant. Thèse de Doctorat, Université de Clermont II, $N^{\circ}$ d'ordre 256, 2 vol, $195 p$

Jouany JP (1991) Defaunation of the rumen. In: Rumen Microbial Metabolism and Ruminant Digestion (JP Jouany, ed) INRA Editions, Versailles, France, 239-261

Jouany JP, Senaud J (1982) Influence des ciliés du rumen sur la digestion de différents glucides chez le mouton. I. Utilisation des glucides pariétaux (cellulose et hémicelluloses) et de l'amidon. Reprod Nutr Develop 22, 735752

Jouany JP, Demeyer DI, Grain J (1988) Effect of defaulating the rumen. Anim Feed Sci Technol 21, 229-265

Jouany JP, Zainab B, Senaud J, Grolière CA, Grain J, Thivend P (1981) Role of the rumen ciliate protozoa Polyplastron multivesiculatum, Entodinium sp, and Isotricha prostoma in the digestion of a mixed diet in sheep. Reprod Nutr Develop 21, 871-884

Jouany JP, Fonty G, Lassalas B, Doré J, Gouet $P$, Bertin G (1991) Effect of live yeast cultures on feed degradation in the rumen as assessed by in vitro measurements. Conference on Rumen Function, Chicago, USA, abstract $n^{\circ} 6,7$

Kiessling KH, Pettersson H, Sandholm K, Olsen $M$ (1984) Metabolism of aflatoxin, zealarenone and trichotecenes by intact rumen fluid, rumen protozoa and rumen bacteria. Appl Environ Microbiol 47, 1070-1073

Kurihara Y, Takechi T, Shibata F (1978) Relationship between bacteria and ciliate protozoa in the rumen of sheep fed on a purified diet. J Agric Sci 90, 373-381

MacGregor RC, Armstrong DG (1984) The feed antibiotic avoparcin and net uptake of amino acids from the small intestine of sheep. Can J Anim Sci 64, 134-135 
Meyer JMF, Van der Walt SI, Schwartz HM (1986) The influence of diet and protozoal numbers on the breakdown and synthesis of protein in the rumen of sheep. J Anim Sci 62, 509-520

Nagaraja TG, Avery TB, Galitzer SJ, Harmon DL (1985) Effect of ionophore antibiotics on experimentally induced lactic acidosis in cattle. Am J Vet Res 46, 2444-2452

Orskov ER, McDonald I (1979) The estimation of protein degradability in the rumen from incubation measurements weighed according to rate of passage. J Agric Sci 92, 499-503

Prins RA, Van Nevel CJ, Demeyer DI (1972) Pure culture studies of inhibitors for methanogenic bacteria. Antonic Leeuwenhoek, J Microbiol Serol 38, 281-287

Raun AP, Cooley CO, Potter EL, Rathmacher RP, Richardson LF (1976) Effect of monensin on feed efficiency of feedlot cattle. $J$ Anim Sci 43, 670-677

Rogers $M$, Jouany JP, Thivend $P$, Fontenot $P$ (1991) Comparative effects of feeding and duodenal infusion of monensin on digestion in sheep. Can J Anim Sci71, 1125-1133

Rowe JB, Davies A, Broome AWJ (1985) Quantitative effects of defaunation on rumen fermentation and digestion in sheep. Br J Nutr $54,105-119$

Russell JB, Martin SA (1984) Effects of various methane inhibitors on the fermentation of amino acids by mixed rumen microorganisms in vitro. J Anim Sci 54, 1040-1050

Sparling $R$, Daniels L (1987) The specificity of growth inhibition of methanogenic bacteria by bromoethanesulfonate. Can J Microbiol $33,1132-1136$

Spears JW, Harvey RW (1984) Performance, ruminal and serum characteristics of steers fed lasalocid on pasture. J Anim Sci 58, 460-464

Ushida K, Jouany JP (1985) Effect of protozoa on rumen protein degradation in sheep. Reprod Nutr Develop 25, 1075-1081

Ushida K, Jouany JP, Demeyer DI (1991) Effects of presence or absence of rumen protozoa on the efficiency of utilization of concentrate and fibrous feeds. In: Physiological Aspects of Digestion and Metabolism in Ruminants ( $T$ Tsuda, $Y$ Sasaki, $R$ Kawashima, eds) Academic Press, Tokyo, Japan, 625-654

Ushida K, Jouany JP, Thivend P (1986) Role of rumen protozoa in nitrogen digestion in sheep given two isonitrogenous diets. $\mathrm{Br} \mathrm{J}$ Nutr 56, 407-419

Ushida K, De Smet S, Kayouli C, Jouany JP (1989) Effect of defaunation on nitrogen digestion in sheep fed ammonia-treated straw with or without maize. $I n$ : The Role of Protozoa and Fungi in Ruminant Digestion (JV Nolan, RA Leng, DI Demeyer, eds) Penambul Books, Armidale NSW 2351, Australia, 309-310

Ushida K, Kayouli C, De Smet S, Jouany JP (1990) Effect of defaunation on protein and fibre digestion in sheep fed ammonia-treated straw-based diets with or without maize. $\mathrm{Br} \mathrm{J}$ Nutr 64, 765-775

Vanbelle M, Teller E, Focant M (1990) Probiotics in animal nutrition: a review. Arch Anim Nutr, Berlin, 40, 543-567

Van Nevel CJ (1991) Modification of rumen fermentation by the use of additives. I $n$ : Rumen Microbial Metabolism and Ruminant Digestion (JP Jouany, ed) INRA Editions, Versailles, France, 263-280

Van Nevel CJ, Demeyer DI (1988) Manipulation of rumen fermentation. In: The Rumen Ecosystem (PN Hobson, ed) Elsevier Science Publishers Ltd, London, 387-443

Villareal Arredondo JF (1988) Effets d'une addition de monensin ou d'aliment concentré sur la reproduction des bovins à viande sousalimentés: reprise de l'activité ovarienne post-partum chez la vache ; secrétion de $\mathrm{LH}$ chez le taureau. Thèse de Doctorat Université de Rennes, Section "Agronomie», $99 \mathrm{p}$

Whitelaw FG, Eadie JM, Bruce LA, Shand WJ (1984) Methane production in faunated and ciliate-free cattle and its relationship with rumen volatile fatty acid proportions. Br J Nutr 52, 261-275

Williams PEV, Newbold CJ (1990) Rumen probiosis: the effects of novel microorganisms on rumen fermentation and ruminant productivity. Rec Adv Anim Nutr (Haresign DJA, Cole W, eds) Butterworths, London, 211-227

Wiedmeier RD, Arambel MJ, Lamb RC, Marcinkowski DP (1987) Effect of mineral salts, carbachol and pilocarbine on nutrient digestibility and ruminal characteristics in cattle. $J$ Dairy Sci 70, 592-600

Wohlt JE, Finkelstein AD, Chung CH (1991) Yeast culture to improve intake, nutrient digestibility and performance by dairy cattle during early lactation. J Dairy Sci 74, 13951400 